\title{
Primary cutaneous anaplastic large-cell lymphoma - Case report ${ }^{*}$ Linfoma cutâneo primário de grandes células anaplásicas - Relato de caso
}

\author{
Luciana Silveira Rabello de Oliveira ${ }^{1}$ \\ Maira Gomes Monteiro ${ }^{3}$
}

\author{
Madeleyne Palhano Nobrega ${ }^{2}$ \\ Wagner Leite de Almeida ${ }^{4}$
}

DOI: http://dx.doi.org/10.1590/abd1806-4841.20131731

\begin{abstract}
Primary cutaneous anaplastic large-cell lymphoma is part of the spectrum of CD30+ lymphoproliferative cutaneous processes, characterized by single or multifocal nodules that ulcerate, are autoregressive and recurrent. Extracutaneous dissemination may occur, especially to regional lymph nodes. Histology shows a diffuse, non-epidermotropic infiltrate, anaplastic large lymphoid cells of immunohistochemistry CD30+, CD4+, EMA-/+, ALK-, CD15- and TIA1-/+. Prognosis is good and does not depend on lymphatic invasion. Radiotherapy, removal of the lesion and/or low-dose methotrexate are the treatments of choice. The present study reports the case of a 57-year-old-woman presenting Primary cutaneous anaplastic large-cell lymphoma with multifocal lesions. The pacient evolved with pulmonary involvement 7 years later. She showed a good response to the treatment with low-dose methotrexate prescribed weekly.

Keywords: Lymphoma, large-cell, anaplastic; Lymphoma, primary cutaneous anaplastic large cell; Lymphoma, T-cell; Lymphoma, T-cell, cutaneous
\end{abstract}

Resumo: Linfoma cutâneo primário de grandes células T anaplásicas faz parte do espectro de processos linfoproliferativos cutâneos CD30+ e caracteriza-se por nódulos únicos ou multifocais, ulcerados, autorregressivos e recidivantes. Pode haver disseminação extracutânea, principalmente para linfonodos regionais. O histológico mostra infiltrado difuso, não-epidermotrópico, grandes células linfóides anaplásicas de imunohistoquímica CD30+, CD4+, EMA-/+, ALK-, CD15- e TIA1-/+. O prognóstico é bom e independe da invasão ganglionar. Radioterapia, retirada da lesão e/ou metotrexato em baixas doses são os tratamentos de escolha. Este estudo relata o caso de uma mulher, 57 anos, com Linfoma cutâneo primário de grandes células T com lesões multifocais e que, após 7 anos, evoluiu com acometimento pulmonar. Apresentou boa resposta ao tratamento com metotrexato em baixas doses semanais.

Palavras-chave: Linfoma anaplásico de células grandes; Linfoma anaplásico cutâneo primário de células grandes; Linfoma cutâneo de células T; Linfoma de células T

\section{INTRODUCTION}

The primary cutaneous anaplastic large cell lymphoma (PCALCL) is a non-Hodgkin lymphoma (NHL) of cutaneous T-cell presentation, without systemic involvement at the time of the diagnosis and in the next six months. It has been well-established that PCALCL express the CD30 antigen in more than 75\% of their tumor cells. ${ }^{1}$ The incidence of PCALCL among other types of peripheral T-cell NHL is 1.7\%. It reaches an overall peak in the sixth decade of life and an average of $50 \%$ of cases are diagnosed in patients aged $61 .^{2}$
Most patients present with solitary or localized nodules, papules or plaques. However, up to $20 \%$ of patients may have multiple lesions. Ulceration may be present or not. The lesions usually occur on the trunk, face, extremities and buttocks and are usually asymptomatic. ${ }^{3}$ Histologically, these lesions show a diffuse infiltrate composed of large sized $\mathrm{T}$ lymphocytes with characteristic morphology of anaplastic cells with round, oval or irregular nuclei, prominent eosinophilic nucleoli and abundant cytoplasm; normally, they do not present with epidermotropism. ${ }^{1,3}$

\footnotetext{
Received on 25.02.2012.

Approved by the Advisory Board and accepted for publication on 12.11.2012.

* Work performed at the University Hospital Alcides Carneiro - Federal University of Campina Grande (HUAC-UFCG) - Campina Grande (PB), Brazil. Conflict of interest: None

Financial funding: None

MD, Dermatologist - Master's degree in Public Health - Professor at the Federal University of Campina Grande (UFCG) - Campina Grande (PB), Brazil. MD, Endocrinologist at the Center for Endocrinology and Metabolism - Campina Grande (PB), Brazil.

MD, Immunologist at the University Hospital Alcides Carneiro - Federal University of Campina Grande (HUAC-UFCG) - Campina Grande (PB), Brazil.

MD, Pathologist at the Campinense Unit of Diagnosis - Campina Grande (PB), Brazil. 
The immunophenotype consists of CD4+, CD30+, CLA+, EMA-/+, TIA1-/+, and CD15-ALK-3.

The diagnosis of cutaneous lymphomas is difficult and often delayed, because of the large number of differential diagnoses involving the entire spectrum of primary or secondary CD30+ cutaneous processes.

The main differential diagnoses include lymphomatoid papulosis (LP) and systemic anaplastic large cell lymphoma with cutaneous involvement. ${ }^{4}$

To distinguish PCALCL and LP, longitudinal observation is often necessary as the histopathological differentiation between the two conditions is difficult. $\mathrm{LP}$ lesions are smaller $(<3 \mathrm{~cm})$. Although more diffuse, they are self-limited and do not progress with time.,

Regarding systemic lymphoma, it is more common in young men, under 35 years old, presenting with disease in stage III or IV with lymphadenopathy, B symptoms and a short and progressive course, besides presenting translocation $t$ (2.5) expressing $\mathrm{ALK}+{ }^{3,6}$

It is an indolent neoplasm with good prognosis and five-year survival rate between $76 \%$ and $96 \%$. $^{7}$ Cutaneous recurrences are frequent (39\%) and extracutaneous dissemination occurs in about $13 \%$ of cases, mainly to regional lymph nodes. ${ }^{8}$

Radiation therapy, removal of the lesion and/or low-dose methotrexate are the preferred treatments among patients with localized lesions. ${ }^{3}$ Rapidly progressive or extracutaneous disease should be treated with systemic polychemotherapy. ${ }^{2}$

In this paper, a case of primary cutaneous CD30+ anaplastic large T-cell lymphoma is reported for its exuberance and rarity.

\section{CASE REPORT}

A woman, aged 57, female, from Campina Grande-PB, has had skin lesions since 2001. The lesions began as eczema located in upper and lower limbs that have evolved to a widespread scaly and quite pruritic rash with papules and nodules which ulcerated and spontaneously regressed, leaving permanent hypochromic stains (Figures 1 and 2).

She did outpatient treatment with a specialist since the onset of disease, but she only received a definitive diagnosis in 2007 (after six years of evolution). Until the diagnosis, she had been given oral antihistamines and topical steroids, without improvement. She also needed hospitalizations for secondary infections.

She underwent three skin biopsies (in 2004, 2006 and 2007); the first two were not conclusive.

The lesion biopsy performed in 2007 showed infiltration of atypical lymphoid cells of medium and large sizes in the superficial and reticular dermis and in the subcutaneous tissue with significant eosinophil- ia (Figure 3) suggesting the creation of a immunohistochemical panel for cancer that was positive for CD30 , CD3 and CD15 markers and negative for Ki67 and ALK.

As for the diagnosis, tomography of the chest showed several nodules scattered throughout the parenchyma of both lungs (Figure 4).

Treatment was initiated with methotrexate in weekly doses and achieved good clinical response.

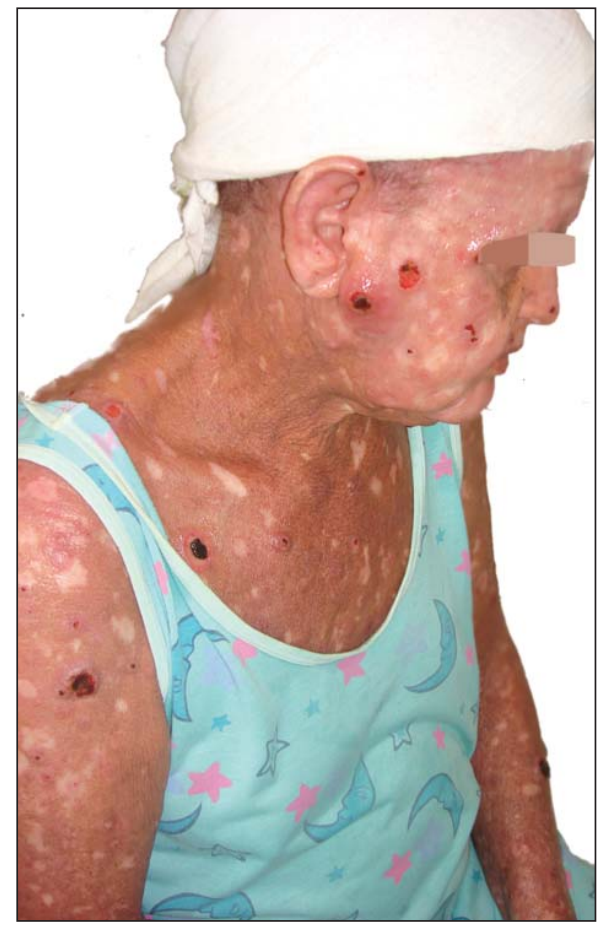

Figure 1:

Widespread scaly eruption with ulcerated nodules and scarring hypochromic spots

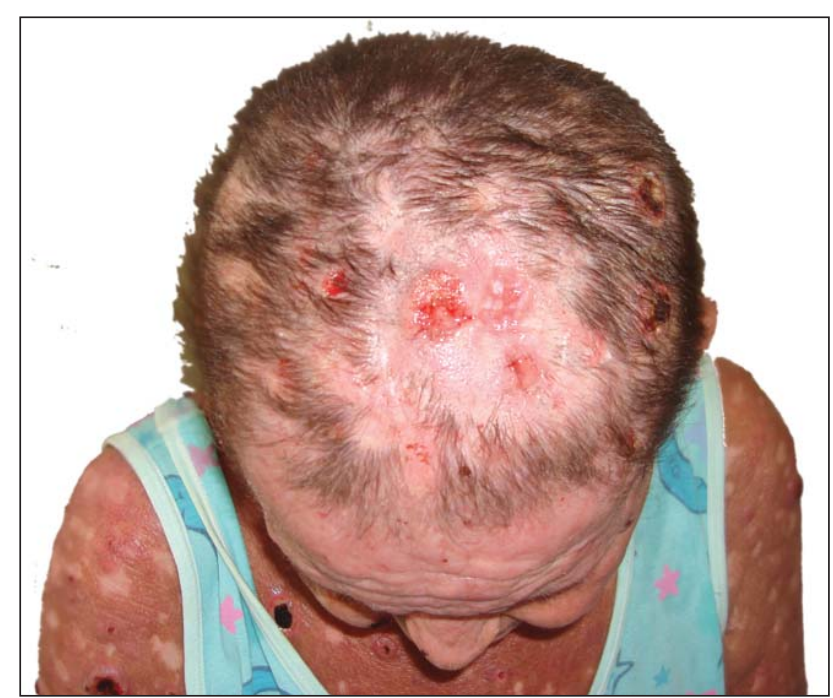

FIGURE 2: Lesions on scalp 


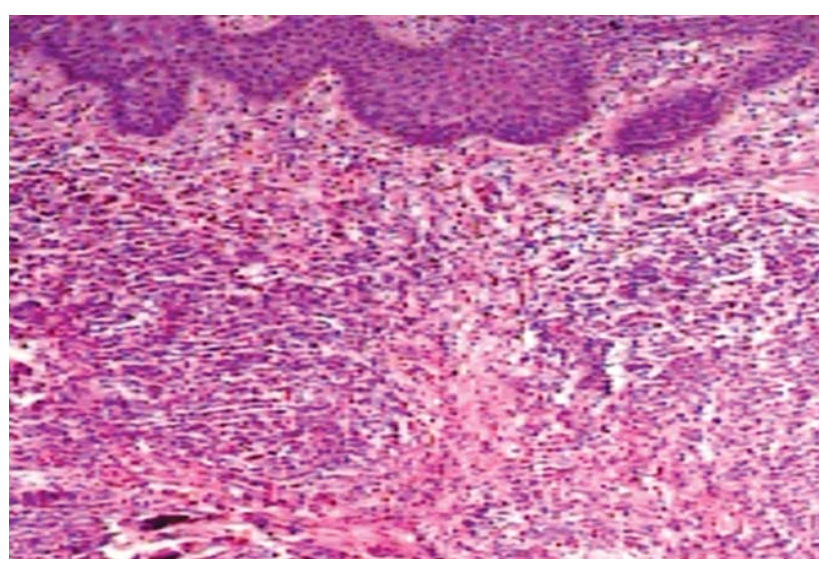

FIGURE 3: Infiltration of medium and large atypical lymphoid cells in the superficial and reticular dermis and in the subcutaneous tissue, with significant eosinophilia

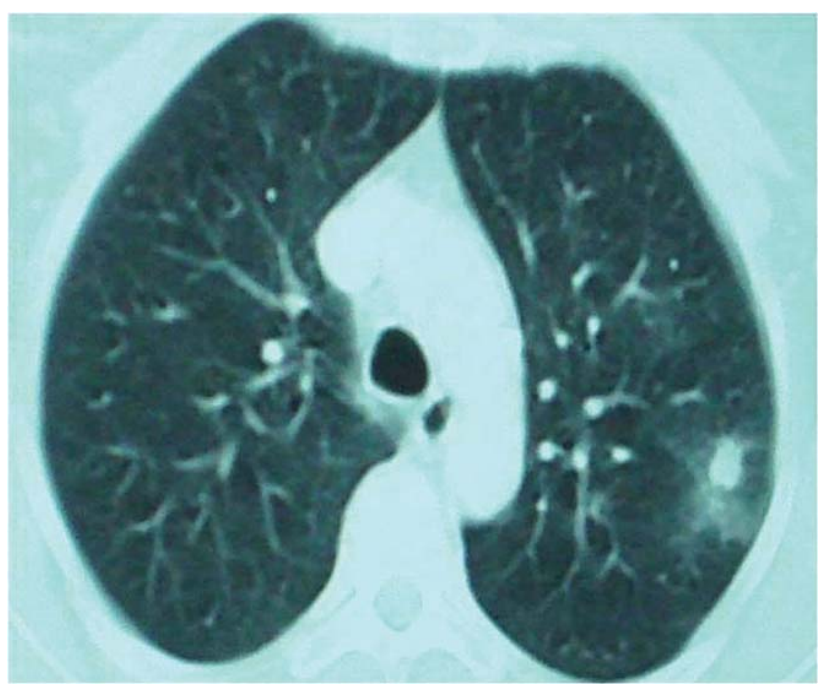

FIGURE 4: Chest CT scan showing parenchymal nodule in the left hemithorax

\section{DISCUSSION}

A case of CD30+ PCALCL in a 57-year-old woman was reported. In the literature, this type of lymphoma affects more frequently males than females with a ratio of 1.5-2:1.,2 Regarding the age group, it affects more adults in the sixth decade of life $e^{4}$ and the aforementioned patient is close to this age group.

Most patients with PCALCL present with localized lesions and up to $20 \%$ of patients may have multiple lesions. ${ }^{2}$ In this case, the lesion was characterized by a scaly and quite pruritic rash with multiple papular and nodular ulcerated lesions, disseminated throughout the body. The lesions improved spontaneously as well as regressed, which is consistent with recent literature.

The most common form of systemic involvement is regional lymph nodes, but the patient had an atypical systemic involvement on lung, after seven years of evolution. ${ }^{6,8}$

Considering the size of the lesions presented and their progression over the years, the differential diagnosis between LP and PCALCL favored lymphoma.

Systemic lymphoma was ruled out as the patient had no other complaints, except those related to skin lesions; no systemic involvement was revealed on the onset of disease and until seven years later (CT and myelogram normal); ALK+ was not expressed; and a good prognosis was shown.

The treatment with methotrexate in weekly doses proved effective, as shown in literature, in which with a $15-20 \mathrm{mg}$ weekly, response occurs in approximately $87 \%$ of patients. ${ }^{8}$

This case report shows the importance of defining the diagnosis to individualize treatment, avoiding aggressive conduct for treating a disease with good prognosis, despite the exuberance of clinical manifestation. Regardless of good prognosis, it is necessary to closely monitor these patients because of the potential risk of dissemination or extracutaneous spread, besides recurrence of the disease or even development of other malignancies, such as mycosis fungoides, Hodgkin or non-Hodgkin lymphomas.] 


\section{REFERENCES}

1. Kempf W, Pfaltz K, Vermeer MH, Cozzio A, Ortiz-Romero PL, Bagot M, et al. EORTC, ISCL, and USCLC consensus recommendations for the treatment of primary cutaneous CD30-positive lymphoproliferative disorders: Iymphomatoid papulosis and primary cutaneous anaplastic large-cell lymphoma. Blood. 2011;118:4024-35.

2. Diamantidis MD, Papadopoulos A, Kaiafa G, Ntaios G, Karayannopoulou G, Kostopoulos I, et al. Differential diagnosis and treatment of primary, cutaneous, anaplastic large cell lymphoma: not always an easy task. Int J Hematol. 2009;90:226-9.

3. Diamantidis MD, Myrou AD. Perils and Pitfalls Regarding Differential Diagnosis and Treatment of Primary Cutaneous Anaplastic Large-Cell Lymphoma. ScientificWorldJournal. 2011;11:1048-55.

4. Kadin ME. Current management of primary cutaneous CD30+ T-cell lymphoproliferative disorders. Oncology (Williston Park). 2009;23:1158-64.

5. Duvic M. Improved understanding of peripheral T-cell lymphomas. Oncology (Williston Park). 2010;24:587, 592-3.

6. Benner MF, Willemze R. Applicability and prognostic value of the new TNM classification system in 135 patients with primary cutaneous anaplastic large cell lymphoma. Arch Dermatol. 2009;145:1399-404.

7. Liu HL, Hoppe RT, Kohler S, Harvell JD, Reddy S, Kim YH. CD30+ cutaneous lymphoproliferative disorders: the Stanford experience in lymphomatoid papulosis and primary cutaneous anaplastic large cell lymphoma. J Am Acad Dermatol. 2003:49:1049-58.

8. Bekkenk MW, Geelen FA, van Voorst Vader PC, Heule F, Geerts ML, van Vloten WA, et al. Primary and secondary cutaneous CD30+ lymphoproliferative disorders: a report from the Dutch Cutaneous Lymphoma Group on the long-term follow-up data of 219 patients and guidelines for diagnosis and treatment. Blood. 2000;95:3653-61.

\author{
MAILING ADDRESS: \\ Madeleyne Palhano Nobrega \\ 840 Arquilino de Souza Guimaraes St. \\ 58402-030 - Campina Grande - PB \\ Brazil \\ E-mail: madeleynepalhano@ig.com.br
}

How to cite this article: Oliveira LSR, Nóbrega MP, Monteiro MG, Almeida WL. Primary cutaneous anaplastic large-cell lymphoma: Case report. An Bras Dermatol. 2013;88(6 Suppl 1):S132-5. 